\title{
Group decision making during queen production in colonies of highly eusocial bees
}

\author{
David R. TARPYa*, David C. GILLEY ${ }^{\mathrm{b}}$ \\ ${ }^{a}$ Department of Entomology, Campus Box 7613, North Carolina State University, Raleigh, NC 27695-7613, USA \\ ${ }^{\mathrm{b}}$ Carl Hayden Bee Research Center, 2000 East Allen Road, Tucson, AZ 85719-1596, USA
}

(Received 30 July 2003; revised 5 November 2003; accepted 30 November 2003)

\begin{abstract}
Colonies of social insects make numerous group decisions about foraging, nest maintenance, and reproduction. Queen production is a task whereby a colony's workers may exercise choices over which individuals to rear as gynes (unmated queens) and which gynes will survive to ultimately become queens. Here we assess the potential for how colonies of highly eusocial bees may exhibit such group decisions by reviewing the behaviors of stingless bee and honey bee workers during the gyne rearing, emergence, and elimination stages of queen production. We demonstrate that although the specific mechanisms whereby such decisions are manifested may vary among the taxa, there is a high potential for group decision making during queen production in eusocial bees. Given the importance of a queen to the inclusive fitness of all nestmates, such group decisions are likely to have a profound influence on the reproductive success of highly eusocial bee colonies. We briefly entertain the evolutionary mechanisms that may have shaped these group decision-making processes.
\end{abstract}

queen rearing / group decision making / queen elimination / colony reproduction / highly eusocial bees

\section{INTRODUCTION}

Most colonies of highly eusocial bees (Meliponinae, Apinae) have only one queen for the majority of their life cycle (Wilson, 1971). Multiple gynes (unmated queens), however, may temporarily coexist within a colony during queen replacement or reproductive colony fission (also known as "swarming"). During these two events, colonies typically produce more gynes than are needed to serve as queens for the parent and offspring colonies, thus the excess gynes are eliminated from the colony by a variety of means (Michener, 1974). The processes whereby gynes are reared and queens are chosen from among the available gynes (hereafter referred to as 'queen production') are undoubtedly targets of natural selection because queens are of great importance to the inclusive fitness of all colony members. In this review we consider queen production as an adaptive group decision made by the workers of eusocial bee colonies.

The primary objective of this paper is to review the mechanisms by which highly eusocial bees, specifically stingless bees (tribes Meliponini and Trigonini) and honey bees (genus Apis, primarily A. mellifera), make group decisions during queen production. We focus on two group decisions: which brood is reared as gynes and which gynes survive to become queens. For each stage of the queenproduction process (gyne rearing, gyne emergence, gyne elimination) we evaluate the potential for group decisions by the workers and examine the evidence for worker involvement. By "group" we mean either all the workers of a colony or closely related groups of workers within the colony (i.e., patrilines); we do not discuss spatial or task-related groups of

\footnotetext{
* Corresponding author: david_tarpy@ncsu.edu
} 
workers because natural selection is less likely to act on groups at these levels (see Discussion).

The behavior of the workers during queen production is relatively well known for honey bees (reviewed by Winston, 1987), but is less well known for stingless bees, largely because the taxon includes many species with diverse behavior. However, group decision making during queen production is as likely for the workers of stingless bee colonies as for honey bee colonies, thus we consider them where available knowledge permits. We also wish to acknowledge that the behavior of gynes themselves can have an influence on the outcome of queen production. For example, honey bee gynes often produce audible 'piping' sounds that delay the emergence of other mature gynes (Simpson and Cherry, 1969; Bruinsma et al., 1981) and production of this signal is correlated with a gyne's probability of survival (Schneider and DeGrandi-Hoffman, 2003). There are numerous other examples (Post et al., 1987; Page et al., 1988; Imperatriz-Fonseca and Zucchi, 1995; Bernasconi et al., 2000; Gilley, 2001; Tarpy and Fletcher, 2003; Schneider and DeGrandi-Hoffman, 2003; Tarpy et al., 2004), but we focus our review on the workers because as a result of their numerical majority, they ultimately have the power to decide the outcome of queen production.

\section{GYNE REARING}

\subsection{The potential for group decision making during gyne rearing}

Gyne rearing is a complex, time-consuming task that requires extensive cooperation among a colony's workers. Most stingless bee colonies produce gynes continuously throughout the year (Roubik, 1989; Engels and Imperatriz-Fonseca, 1990). For example, in Melipona favosa and M. trinitatis, gynes comprise, on average, approximately $5 \%$ of a colony's female population, although their relative proportions may vary from month to month (Sommeijer et al., 2003c). Honey bee colonies, however, rear relatively few gynes (about 5-25) and only under certain conditions, namely during annual colony reproductive fission or following queen loss or failure (known as "emergency queen rearing" and "supersedure", respectively; reviewed by Winston, 1987). Gyne rearing begins when workers construct special cells in which gynes will develop. In stingless bee colonies, workers mass provision these "royal" cells with brood food through a highly ritualized provision and oviposition process, or POP (see reviews by Michener, 1974; Sakagami, 1982; see also Toth et al., 2002; Toth et al., 2003). Workers seal the cells shortly after the queen oviposits, so that the entire process of cell provisioning, oviposition, and cell closure occurs within approximately 10 minutes. In honey bee colonies, workers continually provision royal cells with royal jelly, and the cells are sealed with wax 24 hours before the developing gynes pupate. The total development time of a gyne is approximately 15-16 days for honey bees (DeGrandi-Hoffman and Watkins, 1998) and several weeks for most stingless bee species (Roubik, 1989).

The time required to rear gynes gives workers the opportunity to decide as a group which developing larvae or pupae are given an advantage over others to become gynes (Tab. I). Before a royal cell is sealed, the workers can manipulate a developing gyne's nutrition by altering the quantity or quality of her provisions. Gyne larvae that are provided with more or higher-quality food may have a better chance of becoming a gyne. Group decision making before cell capping is more likely for honey bees than for stingless bees because workers continually feed gyne brood rather than mass provision them. After a royal cell is sealed, the workers can affect the development of the occupant by altering their incubation behavior. Gyne brood is highly sensitive to temperature (DeGrandi-Hoffman et al., 1993; Bujok et al., 2002), thus pupae whose cells are maintained at an ideal temperature may have a better chance of becoming a gyne than those that are not. The workers can also decide to destroy a royal cell at any time during the gyne-rearing process.

\subsection{Evidence for group decision making during gyne rearing}

Strong evidence for a group decision during gyne rearing would consist of both 
Table I. A summary of the potential mechanisms of group decision making that are exhibited by stingless bee and honey bee workers during the gyne rearing, emergence, and elimination phases of queen production.

\begin{tabular}{rccc}
\hline $\begin{array}{r}\text { Mechanism of bias } \\
\text { Gyne rearing }\end{array}$ & Trigonini & Melipona & Apis \\
Quantity of food & Yes? & Yes? & No \\
Quality of food & $?$ & $?$ & No? \\
Incubate cells & $?$ & $?$ & Yes \\
Destroy cells & No & No? & Yes? \\
Prisons & Yes & & \\
Gyne emergence & No & No & Yes? \\
Prevent or delay emergence & No & No & Yes \\
Protect cells & No & No? & Yes \\
Regulate emergence order & & & \\
Gyne elimination & & & Yes \\
\hline Assassinations by workers & Yes & Yes & Yes \\
Gyne duels & Yes? & No & Yes \\
\hline Assassinations by rival gynes & No & & \\
\hline
\end{tabular}

(a) a demonstration of differential treatment of gyne-destined eggs, larvae, or pupae by the workers, and (b) a demonstration that such treatment affects which individuals successfully emerge as adults. There is virtually no evidence for either condition in stingless bees, largely due to a lack of available studies on the topic. However, there is ample evidence for both conditions in honey bees. First, honey bee workers do not incubate all royal cells at the same temperature. Queen cells that are located at the periphery of the brood nest experience lower temperatures, which negatively affects their development (DeGrandi-Hoffman et al., 1993). However, this differential treatment of royal cells might be a result of the spatial dynamics of workers within a nest, and may not indicate group decision making. Second, during the incubation period, workers often "shake" royal cells (known as the vibration or shaking signal; see Schneider and Lewis, 2004) by vibrating their bodies dorsoventrally for 1-2 seconds at approximately $16 \mathrm{~Hz}$ (Fletcher, 1978; see Seeley et al., 1998). Some cells are shaken as much as three times the rates of other cells (Fletcher, 1978), but shak- ing rate is not associated with emergence success (Schneider et al., 2001). However, royal cells that are initiated earlier in the gyne-rearing process are visited, incubated, and shaken more often and have greater emergence success than cells initiated later (Schneider and DeGrandi-Hoffman, 2002). Together, these findings suggest that shaking rates do not affect emergence success directly, but rather covary with other determinants of emergence success. Third, honey bee workers destroy royal cells non randomly. During 'emergency queen rearing', the probability that workers tear down a fully constructed royal cell depends on the age of the brood around which the cell is built (Hatch et al., 1999; Schneider and DeGrandi-Hoffman, 2002). Because queen reproductive quality is a decreasing function of the age of a larva when it is initially reared as a queen (Woyke, 1971; Gilley et al., 2003), this suggests that workers may selectively destroy cells that contain lesser-quality gynes to raise the average reproductive quality of surviving gynes (Hatch et al., 1999). The absolute age of worker brood from which gynes are reared also affects the chance that 
the workers destroy the cell (Tarpy et al., 2000). Finally, there has been a concerted effort to document nepotism during gyne rearing in honey bees (reviewed by Breed et al., 1994; Visscher, 1998; Tarpy et al., 2004). The differences in relatedness among different subfamilies within colonies create the potential for workers to bias gyne rearing in favor of super-sister gynes $(G=0.75)$ over half-sister gynes $(G=0.25)$. Although some studies have demonstrated significant biases towards certain gynes, the collective evidence suggests that little if any bias is manifested towards super-sisters. Nevertheless, it appears that there is good evidence that workers make group decisions during the gyne rearing process.

\section{GYNE EMERGENCE}

Highly eusocial bee workers often confine, or "imprison", fully developed adult gynes at or near the time of their emergence. In many Trigona species, workers construct prisons of cerumen around gynes soon after they emerge (reviewed by Sakagami, 1982; ImperatrizFonseca and Zucchi, 1995). The workers feed a gyne through an opening in the prison and do not allow the queen or aggressive workers to approach. In some species, gynes facilitate this process by entering empty storage pots that the workers turn into prisons, or by helping to construct the prisons themselves. Other genera in the Trigonini (e.g., Celetrigona and Leurotrigona) form a prison of adult workers that encircles a gyne to form a dense barrier that moves with her. Honey bee workers often imprison gynes for days in the cells in which they develop, feeding them through slits cut into the cell cap (Huber, 1792; see Mangum, 1998). Workers in the Melipona do not imprison adult gynes in any way (ImperatrizFonseca and Zucchi, 1995).

The adaptive significance of gyne imprisonment is not well understood, but it is an ideal opportunity for the workers to compare mature gynes and decide as a group which they will allow to become queens (Tab. I). Some evidence suggests that honey bee workers may exercise such decisions. For example, worker shaking of imprisoned gynes increases over time (Fletcher, 1978) and is positively associated with the emergence order of gynes within a colony (Schneider et al., 2001). Moreover, workers can control when gynes emerge from their prisons (relative to other gynes) by adding or removing wax from the cell caps (Simpson and Cherry, 1969; Grooters, 1987; Gilley, 2001). The timing of emergence is closely linked to a gyne's survival (Gilley and Tarpy, unpublished data), and thus may be another mechanism for group choice of queens by honey bee workers. Finally, the rate at which honey bee workers visit imprisoned gynes is associated with the degree of kinship between the imprisoned gyne and the worker (Schneider and DeGrandi-Hoffman, 2002). This suggests that workers may bias queen production in favor of more-closely related gynes. Nonetheless, more studies are needed to determine how workers may regulate gyne emergence and whether particular gynes are preferentially imprisoned or released.

\section{GYNE ELIMINATION}

\subsection{The potential for group decision making during gyne elimination}

There are many opportunities after gynes emerge (either from their cells or prisons) for the workers to decide as a group which ones will become queens. During the gyne elimination stage of queen production, the total number of gynes is reduced to however many are needed as queens. Gynes are eliminated from a colony by several means (Fig. 1). First, they can be killed by the workers. This mechanism of elimination occurs frequently in stingless bees (Michener, 1974; ImperatrizFonseca and Zucchi, 1995) but does not occur at all in honey bees under these circumstances (Gilley and Tarpy, unpublished data). Second, they can be killed by rival gynes during lethal fights or 'duels' (Gilley, 2001). Third, they can be killed by emerged rival gynes before they emerge from their cells. Such 'queen assassinations' (Gilley, 2001) occur frequently in honey bees (Gilley and Tarpy, unpublished data) but have not been reported in stingless bees. Finally, gynes may depart their natal nest to start their own colonies via reproductive fission ("swarming"). In stingless bees, gynes 


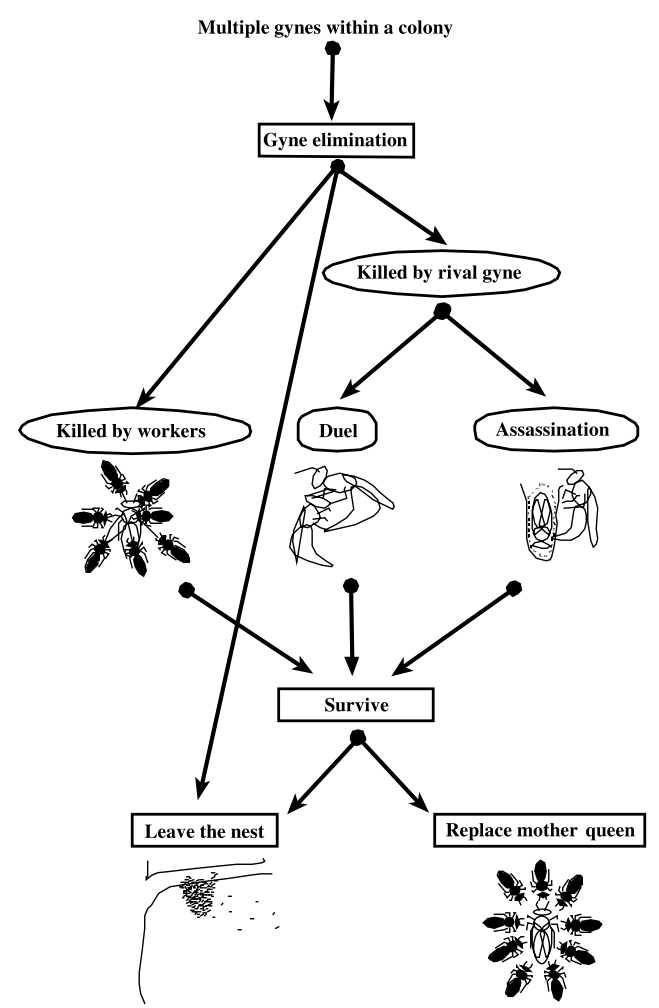

Figure 1. A flow diagram of the gyne elimination process in highly eusocial bee colonies. Gynes may be killed by workers (stingless bees only), or they may be killed by rival gynes during fights (duels) or while imprisoned (assassinations). Gynes that survive the elimination process may either leave the nest or replace the mother queen in the natal nest and inherit the colony. Those that leave the nest depart in swarms or, in the case of some Melipona gynes, leave solitarily to possibly take over a foreign colony.

leave the colony and the mother queen remains in the natal nest, whereas in honey bees, gynes may depart the colony in secondary swarms after the mother queen has already departed in the prime swarm. Melipona gynes may also depart their nest solitarily (Sommeijer et al., 2003b) and usurp a foreign colony (Sommeijer et al., 2003a). In any event, leaving the nest is inherently risky for an unmated queen since the probability of survival can be very low (Seeley and Visscher, 1985; Roubik, 1989; Sommeijer et al., 2003a). Gynes that survive the elimination process may either leave the nest (see above) or replace their mother queen and inherit the colony.

The workers could influence (or determine, in the case of worker-gyne assassination) what happens to particular gynes through their extensive interactions with them during this phase (Tab. I). Both stingless bee and honey bee workers typically bite, chase, and grab gynes soon after they emerge (Sakagami, 1982; Imperatriz-Fonseca and Zucchi, 1995; Gilley, 2001). In Melipona beecheii, gynes that are grabbed and pulled by the workers are killed by them within 20 hours of emergence (van Veen et al., 1999). In other stingless bees, anywhere from a few to dozens of workers may completely dismember virgin queens by twisting off their heads and other body parts (Michener, 1974; Sakagami, 1982; Koedam et al., 1995), and then deposit their remains in the waste dump (Imperatriz-Fonseca and Zucchi, 1995). The harassment of gynes by honey bee workers never results in the death of the gynes (Gilley and Tarpy, unpublished data). However, honey bee gynes are sometimes immobilized by clusters of workers (known as "balling"; Walton and Smith, 1969; Ambrose, 1975; Lensky et al., 1991; Pettis et al., 1998), which might make gynes easier to sting by rivals during gyne duels (Gilley, 2001; Tarpy and Fletcher, 2003). Honey bee workers also frequently shake emerged gynes, as they do royal cells (see above; Fletcher, 1975; Schneider and DeGrandi-Hoffman, 2003). The workers of both stingless bees and honey bees also interact with gynes through trophallaxis, grooming, and antennal contact (Michener, 1974; Sakagami, 1982; Koedam et al., 1995), though the rates of these interactions are relatively low in honey bees (Gilley, 2001). All of these worker-gyne interactions could affect the fates of the gynes and thus may represent group decisions over which gynes survive to become queens and which do not.

\subsection{Evidence for group decision making during gyne elimination}

There is conflicting evidence over whether worker-gyne interactions bias the outcome of gyne elimination in favor of certain individuals. van Benthem et al. (1995) demonstrate that gynes of the morphologically primitive 
Plebeia remota interact extensively with the workers once they emerge from their cells. Those gynes that are not killed immediately are often imprisoned (see above), but it is unclear if certain gynes are chosen to be killed or left alive and on what basis. Gynes are produced continuously, perhaps as a means to constantly test the quality of the mother queen and replace her with a daughter of higher reproductive quality (van Benthem et al., 1995). There is evidence for differential treatment of gynes in Melipona beecheii, where gynes that inflate their abdomens for longer durations are more attractive to workers and are eliminated significantly less often (van Veen et al., 1999). Abdomen inflation may release a pheromone that indicates a gyne's reproductive potential, and so the behavior may be an honest signal of her quality. Honey bee gynes survive duels more often if they are related to the workers of the colony (Tarpy and Fletcher, 1998) and if they are older than their rivals (Tarpy et al., 2000), suggesting that workers may bias the outcome of gyne duels. However, aggressive interactions are not the mechanism for biasing fights in favor of more-related gynes, since workers aggress half-sister and super-sister queens at equal rates (Gilley, 2003). Also, honey bee gynes that receive more shaking signals survive longer and are less likely to be eliminated by their rival gynes (Schneider and DeGrandiHoffman, 2003). However, when gyne quality is manipulated experimentally, the workers show no change in their rates of aggressive or non-aggressive interactions towards gynes of lower reproductive potential (Gilley et al., 2003). Together, the current evidence indicates that the workers may bias the outcome of gyne elimination, but it is unclear by what mechanisms the workers are exerting their decisions.

\section{DISCUSSION}

Our review highlights how workers of highly eusocial bees may exercise choices during the various stages of queen production (Tab. I). Workers may affect the development of certain gynes by differentially feeding, incubating, or destroying royal cells. They may also determine how gynes are introduced into the nest proper by constructing prisons and regulating their emergence from royal cells. Finally, workers may govern the gyne elimination process by differentially killing certain gynes or biasing the outcomes of fatal gyne-gyne interactions.

While the main objective of this review is to highlight the proximate mechanisms that workers may use to exercise group decisions over queen production, here we briefly entertain some of the evolutionary implications of such decisions. Roubik (1989) states that "excessive queen production is necessary...not just to ensure that a queen is available to supersede the mother queen or to form a new colony, but that a particular queen genotype may be selected by the workers or other agents" (his italics). The most logical factor upon which workers may base their decisions is the potential reproductive quality of gynes. Natural selection is likely to favor those colonies that retain the most fecund gyne from among those available. Thus colony-level selection is likely to favor nestmate behaviors that promote the choice of high-quality queens over low-quality queens. By extension, natural selection is expected to favor colonies that maximize their fitness by producing the highest possible number of surviving daughter colonies. Visscher (1993) demonstrates that important ecological factors, such as the probability of colony survival, shape the reproductive decisions of colony members to collectively produce the optimal outcome of reproductive events.

Selection acting at the individual level, however, may cause colony members to have conflicting interests over which gynes survive to become queens. Kin selection theory predicts that individuals will behave in such a way as to maximize their genetic contribution to successive generations (Hamilton, 1964; reviewed by Crozier and Pamilo, 1996). Peters et al. (1999) use a simple kin selection model to demonstrate that reproductive conflict is expected to be low within stingless bee colonies, largely because their queens are predominantly monandrous (Strassmann, 2001). Single mating causes the individual and group interests over which gyne to become the next queen to be aligned among the workers. Within honey bee colonies, however, the potential for conflict is expected to be much 
higher because their queens are highly polyandrous (Tarpy and Nielsen, 2002). Multiple mating can cause the individual and group interests to be in opposition over which gyne or gynes will survive. The relative magnitude of conflict and cooperation within colonies, therefore, depends on various genetic and ecological factors (Visscher, 1993) and the selective pressures acting at the individual and colony levels (Keller and Reeve, 1999; Tarpy et al., in press).

These considerations enable predictions to be made about group decision-making processes during queen production (see also Visscher, 1993). First, stingless bee colonies are expected to choose gynes non-randomly, selecting those with high reproductive potential over those of lower quality. Such cooperation is expected because their workers presumably lack conflict over gyne production as a result of their common genetic interests. By extension, stingless bee colonies headed by polyandrous queens (see Paxton et al., 1999), although relatively rare, might be expected to have increased conflict over queen production. Second, the conflict of interest between workers and gynes is expected to be greater as the number of potential queens increases (Visscher, 1993). This may explain, at least in part, why stingless bee workers often kill gynes but honey bee workers allow gynes to kill each other. Third, worker-gyne conflict over queen production is expected to increase as more reproductive opportunities are available (Visscher, 1993). In honey bees, aggressive behaviors of workers toward gynes seems to occur mainly when a colony is prepared to issue one or more afterswarms (Gilley and Tarpy, unpublished data), suggesting that these behaviors are used to formulate collective decisions during queen production. Finally, if honey bee workers exhibit nepotism during gyne production, it would suggest that individual-level selection is predominant; if colonies primarily exhibit cooperation to raise highquality queens, it would suggest that colonylevel selection is predominant (Tarpy et al., 2004).

We have yet to fully understand the queen production process in highly eusocial bees, as evidenced by the number of uncertainties in Table I. This is particularly true for stingless bees, since their diversity and breadth of behavior make it difficult to draw general conclusions about them. Nonetheless, insights into queen production will enable future efforts in determining why colonies of social bees chose particular queens over others, and how such decisions have been shaped by natural selection.

\section{ACKNOWLEDGMENTS}

We would like to thank Koos Biesmeijer and Judith Slaa for making comments and suggestions on the manuscript. Funding for DRT was provided by NSF grant IBN-973-4181 and USDA grant 031441 , and to DCG by NSF grant 0104929.

Résumé - Prise de décision collective lors de la production de reines dans les colonies d'abeilles eusociales. Lorsque les colonies d'abeilles eusociales supérieures (Meliponinae, Apinae) produisent de nouvelles reines, elles élèvent normalement plus de jeunes reines qu'il n'en survivra. Ce processus permet aux ouvrières d'exercer des choix sur les femelles qui survivront et deviendront reines. Dans cet article nous évaluons le potentiel de prise de décision collective durant la production de reines en passant en revue les comportement des ouvrières d'abeilles sans aiguillon et d'abeilles mellifères au cours des stades d'élevage, d'éclosion et d'élimination des reines.

Les abeilles sans aiguillon comme les abeilles mellifères peuvent influer sur le développement des reines en variant l'incubation, en interagissant avec les cellules royales et en les détruisant avant l'éclosion. Comparée aux abeilles mellifères, dont les ouvrières nourrissent continuellement le couvain femelle, la décision collective de décider quels individus seront élevés en reine est moins probable chez les abeilles sans aiguillon, parce que celles-ci ferment les cellules royales après les avoir approvisionnées totalement. Il existe de bonnes preuves de traitement différentiel chez les abeilles mellifères, pas chez les abeilles sans aiguillon, mais ceci est vraisemblablement dû à un manque d'études sur le sujet.

Les abeilles sans aiguillon, comme les abeilles mellifères, régulent l'éclosion des reines dans le nid. De nombreuses espèces de Meliponini construisent des «prisons » avec des matériaux du nid ou avec des ouvrières adultes qui encerclent la reine et restreignent ses mouvements. Les reines d'abeilles mellifères peuvent aussi être emprisonnées dans les cellules où elles se développent. La capacité des ouvrières à agir sur l'éclosion des reines reste mal comprise et les preuves d'une décision collective restent limitées.

Après avoir éclos, les reines peuvent soit quitter le nid, soit y rester. La plupart des reines qui ne quittent pas le nid sont tuées soit par les ouvrières, 
soit par leurs rivales (Fig. 1). Les ouvrières peuvent influencer significativement, par les interactions qu'elles ont avec les reines, le choix des reines qui survivront au processus d'élimination, mais les mécanismes mis en jeu dans ces décisions ne sont pas clairs (Tab. I).

Cette revue montre que, malgré les nombreuses différences nettes entre abeilles sans aiguillon et abeilles mellifères, il existe certains mécanismes communs par lesquels les ouvrières peuvent choisir collectivement quelles femelles survivront et deviendront reines. Étant donné l'importance de la reine dans l'inclusive fitness (succès relatif d'un individu à transmettre ses gènes à la génération suivante) de tous les membres de la colonie, de telles décisions collectives ont probablement une forte influence sur le succès reproductif des colonies d'abeilles eusociales supéreiures. D'autres recherches sur le processus de la production de reines fourniront des indications précieuses sur la sociobiologie des abeilles eusociales supérieures.

abeilles eusociales / élevage de reines / prise de décision collective / élimination des reines / reproduction de la colonie

Zusammenfassung - Gruppenentscheidungen bei der Nachzucht von Königinnen in Völkern von eusozialen Bienen. Bei der Nachzucht neuer Königinnen in Völkern der hoch eusozialen Bienen (Meliponinae, Apinae) werden normalerweise mehr Jungköniginnen erzeugt als überleben können. Dadurch können die Arbeiterinnen eine Auswahl treffen, welches der Geschlechtstiere überlebt und Königin wird. Wir schätzen die Möglichkeiten von Gruppenentscheidungen bei der Aufzucht von Königinnen $a b$, indem wir das Verhalten von stachellosen Bienen und Honigbienen während der Stadien bei der Zucht von Königinnen, bei der Anlage von Nachschaffungszellen und während der Zerstörung von Zellen besprechen.

Beide, Stachellose und Honigbienen können die Entwicklung der Königinnen durch unterschiedliches Wärmen, Interaktionen und Zerstören der Weiselzellen vor ihrem Schlupf beeinflussen. Im Vergleich zu Honigbienen (deren Arbeiterinnen fortwährend die Larven füttern) ist eine Gruppenentscheidung bei der Auswahl bei Stachellosen Bienen weniger wahrscheinlich, weil sie die Königinnenzellen nach einer vollständigen Versorgung mit Futter verschließen. Es gibt gute Beweise über unterschiedliche Pflege bei Honigbienen, nicht aber bei Stachellosen Bienen. Das könnte aber eher am Mangel von diesbezüglichen Untersuchungen liegen.

Sowohl Stachellose Bienen als auch Honigbienen regulieren den Schlupf der Königinnen im Nest. Viele Trigonini Arten bauen „Gefängnisse“ aus Nestmaterial oder adulte Arbeiterinnen beschränken die Bewegung der Königinnen. Königinnen der Honigbienen können auch in ihren Zellen einge- sperrt bleiben, in denen sie sich entwickelten. Die Fähigkeit der Arbeiterinnen, den Schlupf der Königinnen zu beeinflussen, ist noch wenig verstanden und Befunde, die auf Gruppenentscheidungen hinweisen, sind begrenzt.

Nach dem Schlupf können die Königinnen entweder ihr Nest verlassen oder dort bleiben. Die meisten Königinnen, die nicht wegfliegen, werden entweder von den Arbeiterinnen oder durch Rivalinnen getötet (Abb. 1). Die heutigen Befunde zeigen, dass Arbeiterinnen durch intensive Interaktionen einen deutlichen Einfluss darauf nehmen können, welche Königin eine Elimination überlebt. Aber es ist nicht klar, welche Mechanismen sie bei ihren Entscheidung anwenden (Tab. I).

Dieser Überblick zeigt, dass es trotz der deutlichen Unterschiede zwischen Stachellosen Bienen und Honigbienen einige gemeinsame Mechanismen geben muss, durch die Arbeiterinnen als Gruppe entscheiden können, welches der Geschlechtstiere Königin wird. Bei Berücksichtigung der Bedeutung einer Königin für die inklusive Fitness aller Bienen eines Volks, haben solche Gruppenentscheidungen wahrscheinlich einen tiefgreifenden Einfluss auf den Reproduktionserfolg von Völkern der hoch eusozialen Bienen. Weitere Untersuchungen über den Prozess der Erzeugung von Königinnen werden uns wertvolle Einblicke in die Soziobiologie dieser Bienen liefern.

Königinnenzucht / Gruppenentscheidugen / Königinnen Elimination / Volksreproduktion / hoch eusoziale Bienen

\section{REFERENCES}

Ambrose J.T. (1975) Aggressive-behavior of honeybee workers towards foreign queens and an inconsistency with stress-pheromone hypothesis, Can. J. Zool. 53, 69-71.

Bernasconi G., Ratnieks F., Rand E. (2000) Effect of "spraying" by fighting honey bee queens (Apis mellifera L.) on the temporal structure of fights, Insectes Soc. 47, 21-26.

Breed M.D., Welch C.K., Cruz R. (1994) Kin discrimination within honey bee (Apis mellifera) colonies: an analysis of the evidence, Behav. Process. 33, 25-40.

Bruinsma O., Kruijt J.P., van Dusseldorp W. (1981) Delay of emergence of honey bee queens in response to tooting sounds, Proc. K. Ned. Akad. Wet., Ser. C 84, 381-387.

Bujok B., Kleinhenz M., Fuchs S., Tautz J. (2002) Hot spots in the bee hive, Naturwissenschaften 89 , 299-301.

Crozier R.H., Pamilo P. (1996) Evolution of Social Insect Colonies: Sex Allocation and Kin Selection, Oxford University Press, New York.

DeGrandi-Hoffman G., Spivak M., Martin J.H. (1993) Role of thermoregulation by nestmates on 
the development time of honey bee (Hymenoptera: Apidae) queens, Ann. Entomol. Soc. Am. 86, 165-172.

DeGrandi-Hoffman G., Watkins J.C. (1998) Queen development time and the Africanization of European honey bees, Am. Bee J. 138, 467-469.

Engels W., Imperatriz-Fonseca V.L. (1990) Caste development, reproductive strategies and control of fertility in honey bees and stingless bees, in: Engels W. (Ed.), Social Insects: an Evolutionary Approach to Caste and Reproduction, Heidelberg, Germany, Springer-Verlag, pp. 167-230.

Fletcher D.J.C. (1975) Significance of dorsoventral abdominal vibration among honey-bees (Apis mellifera L.), Nature 256, 721-723.

Fletcher D.J.C. (1978) Vibration of queen cells by worker honeybees and its relation to the issue of swarms with virgin queens, J. Apic. Res. 17, 1426.

Gilley D.C. (2001) The behavior of honey bees (Apis mellifera ligustica) during queen duels, Ethology 107, 601-622.

Gilley D.C. (2003) Absence of nepotism in the harassment of dueling queens by honeybee workers, Proc. R. Soc. London Ser. B 270, 20452049.

Gilley D.C., Tarpy D.R., Land B.B. (2003) The effect of queen quality on the interactions of workers and dueling queen honey bees (Apis mellifera L.), Behav. Ecol. Sociobiol. 55, 190-196.

Grooters H.J. (1987) Influences of queen piping and worker behaviour on the timing of emergence of honey bee queens, Insectes Soc. 34, 181-193.

Hamilton W.D. (1964) The genetical evolution of social behaviour. I and II, J. Theor. Biol. 7, 1-52.

Hatch S., Tarpy D.R., Fletcher D.J.C. (1999) Worker regulation of emergency queen rearing in honey bee colonies and the resultant variation in queen quality, Insectes Soc. 46, 372-377.

Huber F. (1792) New Observations on Bees, Hamilton, IL, Dadant.

Imperatriz-Fonseca V.L., Zucchi R. (1995) Virgin queens in stingless bee (Apidae, Meliponinae) colonies: a review, Apidologie 26, 231-244.

Keller L., Reeve H.K. (1999) Dynamics of conflicts in insect societies, in: Keller L. (Ed.), Levels of Selection in Evolution, Princeton, NJ: Princeton University Press, pp. 153-175.

Koedam D., Monge I.A., Sommeijer M.J. (1995) Social interactions of gynes and their longevity in queenright colonies of Melipona favosa (Apidae: Meliponinae), Neth. J. Zool. 45, 480-494.

Lensky Y., Cassier P., Rosa S., Grandperrin D. (1991) Induction of balling in worker honeybees (Apis mellifera $\mathrm{L}$ ) by stress pheromone from koschewnikow glands of queen bees - behavioral, structural and chemical study, Comp. Biochem. Physiol., A-Physiol. 100, 585-594.

Mangum W.A. (1998) Queen emergence and swarming, Am. Bee J. 138, 101-105.
Michener C.D. (1974) The Social Behavior of the Bees. Cambridge, Harvard University Press.

Page R.E. Jr., Blum M.S., Fales H.M. (1988) o-Aminoacetophenone, a pheromone that repels honeybees (Apis mellifera L.), Experientia 44, 270-271.

Paxton R.J., Weissschuh N., Engels W., Hartfelder K., Javier J., Quezada-Euan G. (1999) Not only single mating in stingless bees, Naturwissenschaften $86,143-146$.

Peters J.M., Queller D.C., Imperatriz Fonseca V.L., Roubik D.W., Strassmann J.E. (1999) Mate number, kin selection and social conflicts in stingless bees and honeybees, Proc. R. Soc. London Ser. B 266, 379-384.

Pettis J.S., Westcott L.C., Winston M.L. (1998) Balling behaviour in the honey bee in response to exogenous queen mandibular gland pheromone, J. Apic. Res. 37, 125-131.

Post D.C., Page R.E. Jr., Erickson E.H. (1987) Honeybee (Apis mellifera L.) queen feces: source of a pheromone that repels worker bees, J. Chem. Ecol. 13, 583-591.

Roubik D.W. (1989) Ecology and Natural History of Tropical Bees. Cambridge, Cambridge University Press.

Sakagami S.F. (1982) Stingless bees, in: Hermann H.R. (Ed.), Social Insects, New York: Academic Press, pp. 361-423.

Schneider S.S., DeGrandi-Hoffman G. (2002) The influence of worker behavior and paternity on the development and emergence of honey bee queens, Insectes Soc. 49, 306-314.

Schneider S.S., DeGrandi-Hoffman G. (2003) The influence of paternity on virgin queen success in hybrid colonies of European and African honeybees, Anim. Behav. 65, 883-892.

Schneider S.S., Painter Kurt S., Degrandi Hoffman G. (2001) The role of the vibration signal during queen competition in colonies of the honeybee, Apis mellifera, Anim. Behav. 61, 1173-1180.

Seeley T.D., Visscher P.K. (1985) Survival of honeybees in cold climates: the critical timing of colony growth and reproduction, Ecol. Entomol. $10,81-88$.

Seeley T.D., Weidenmueller A., Kuehnholz S. (1998) The shaking signal of the honey bee informs workers to prepare for greater activity, Ethology 104, 10-26.

Simpson J., Cherry S.M. (1969) Queen confinement, queen piping and swarming in Apis mellifera colonies, Anim. Behav. 17, 271-278.

Sommeijer M.J., Bruijn L.L.M., Meeuwsen F.J.A.J. (2003a) Reproductive behavior of stingless bees: solitary gynes of Melipona favosa (Hymenoptera: Apidae, Meliponini) can penetrate existing nests, Entomol. Ber. 63, 31-35.

Sommeijer M.J., Bruijn L.L.M., Meeuwsen F.J.A.J., Slaa E.J. (2003b) Reproductive behaviour of 
stingless bees: nest departures of non-accepted gynes and nuptial flights in Melipona favosa (Hymenoptera: Apidae, Meliponini), Entomol. Ber. 63, 7-13.

Sommeijer M.J., De Bruijn L.L.M., Meeuwsen F., Martens E.P. (2003c) Natural patterns of caste and sex allocation in the stingless bees Melipona favosa and $M$. trinitatis related to worker behaviour, Insectes Soc. 50, 38-44.

Strassmann J.E. (2001) The rarity of multiple mating by females in the social Hymenoptera, Insectes Soc. 48, 1-13.

Tarpy D.R., Fletcher D.J.C. (1998) Effects of relatedness on queen competition within honey bee colonies, Anim. Behav. 55, 537-543.

Tarpy D.R., Fletcher D.J.C. (2003) "Spraying" behavior during queen competition in honey bees, J. Insect Behav. 16, 425-437.

Tarpy D.R., Gilley D.C., Seeley T.D. (2004) Levels of selection in a social insect: a review of conflict and cooperation during honey bee queen replacement, Behav. Ecol. Sociobiol., DOI: 10.1007/ s00265-003-0738-5.

Tarpy D.R., Hatch S., Fletcher D.J.C. (2000) The influence of queen age and quality during queen replacement in honeybee colonies, Anim. Behav. 59, 97-101.

Tarpy D.R., Nielsen D.I. (2002) Sampling error, effective paternity, and estimating the genetic structure of honey bee colonies (Hymenoptera: Apidae), Ann. Entomol. Soc. Am. 95, 513528.

Toth E., Queller D.C., Imperatriz Fonseca V.L., Strassmann J.E. (2002) Genetic and behavioral conflict over male production between workers and queens in the stingless bee Paratrigona subnuda, Behav. Ecol. Sociobiol. 53, 1-8.

Toth E., Strassmann J.E., Imperatriz-Fonseca V.L., Queller D.C. (2003) Queens, not workers, produce the males in the stingless bee Schwarziana quadripunctata quadripunctata, Anim. Behav. 66, 359-368.

van Benthem F.D.J., Imperatriz-Fonseca V.L., Velthuis H.H.W. (1995) Biology of the stingless bee Plebeia remota (Holmberg) - observations and evolutionary implications, Insectes Soc. 42, 71-87.

van Veen J.W., Sommeijer M.J., Monge I.A. (1999) Behavioural development and abdomen inflation of gynes and newly mated queens of Melipona beecheii (Apidae, Meliponinae), Insectes Soc. 46, 361-365.

Visscher P.K. (1993) A theoretical analysis of individual interests and intracolony conflict during swarming of honey bee colonies, J. Theor. Biol. 165, 191-212.

Visscher P.K. (1998) Colony integration and reproductive conflict in honey bees, Apidologie 29, 23-45.

Walton G.M., Smith M.V. (1969) Balling behavior of worker honeybees, Am. Bee J. 109, 300-301.

Wilson E.O. (1971) The Insect Societies, Cambridge, Harvard University Press.

Winston M.L. (1987) The Biology of the Honey Bee, Cambridge, Harvard University Press.

Woyke J. (1971) Correlations between the age at which honeybee brood was grafted, characteristics of the resultant queens, and results of insemination, J. Apic. Res. 10, 45-55. 